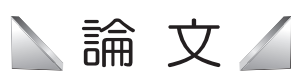

Original Paper

\title{
光ファイバーを利用した多段式岩盤内変位計の開発 *
}

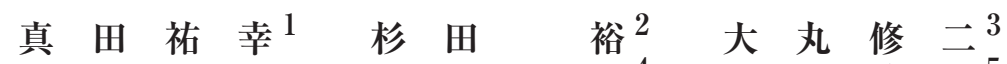 \\ 松井裕哉 4 柏 井善 ${ }^{5}$

\section{Development of a Multi-Level Displacement Sensor using Fiber Bragg Gratings (FBG)}

\author{
by Hiroyuki SANADA ${ }^{a^{*}}$, Yutaka SUGITA ${ }^{\mathrm{a}}$, Shuji DAIMARU ${ }^{\mathrm{b}}$, \\ Hiroya MATSUI ${ }^{\mathrm{c}}$ and Yoshio KASHIWAI ${ }^{\mathrm{d}}$
}
a. Sedimentary Environment Engineering Group, Horonobe Underground Research Unit, Geological Isolation Research and Development Directorate, Japan Atomic Energy Agency (*Corresponding author E-mail: sanada.hiroyuki@jaea.go.jp)
b. Crystalline Environment Research Group, Tono Geoscientific Unit, Geological Isolation Research and Development Directorate, Japan Atomic Energy Agency
c. Crystalline Environment Engineering Group, Tono Geoscientific Unit, Geological Isolation Research and Development Directorate, Japan Atomic Energy Agency
d. TAISEI KISO SEKKEI Co., Ltd.

\begin{abstract}
When the structures such as rock slopes, underground caverns for the geological disposal of high level radioactive waste and underground power plants are constructed, the potential for displacement and damage in the surrounding rock mass is increased due to stress concentration and creep phenomenon. Therefore, the long-term monitoring of rock stability for construction of rock cavern and slopes is important to maintain stability of rock structures. Recently, development of sensors that use optical fiber have expanded mainly in the field of civil engineering and, in rock and soil mechanics, since several parameters such as temperature, strain, pressure, $\mathrm{pH}$ etc. can be obtained by using backscattered light in optical fibers. Additionally, some important advantages using optical fiber are its high resistance to the electric insulation failure, long-term endurance and ability to transmit data over long distances. This paper describes development of a multiple-type displacement sensor using FBG, which has potential for the long-term durability and high accuracy. Laboratory tests were carried out to investigate the relational expression computed from the relationship of the variation in the Bragg wavelength, temperature and displacement. Accuracy of the prototype developed in this research is better than $0.5 \%$ or $1 / 100 \mathrm{~mm}$. The in situ tests involving long-term monitoring using boreholes were conducted to confirm the workability and applicability of the prototype. From the results of the in situ tests, workability is equivalent to the extensometers usually used for long-term monitoring, and the displacement computed from the variation of Bragg wavelength is almost equal to the artificially induced deformation.
\end{abstract}

KEY WORDS: Optic Fiber, FBG, Displacement Sensor, Long-Term Behavior, Geological Disposal, Horonobe URL Project

\section{1. 緒言}

高レベル放射性廃棄物の地層処分においては，坑道の長期的な 安定性評価や処分場の安全評価の観点から処分坑道やアクセス坑

*2009 年 12 月 10 日受付 2010 年 7 月 6 日受理

1. 普通会員博士 (工学) (独) 日本原子力研究開発機構 地層処分研究開発 部門東濃地科学研究ユニット結晶質岩地質環境研究グループ (研究当 時 (独) 日本原子力研究開発機構 地層処分研究開発部門 幌延深地層研究 ユニット 堆積岩工学技術開発グループ)

2. 普通会員 (独) 日本原子力研究開発機構地層処分研究開発部門 幌延深地 層研究ユニット堆積岩工学技術開発グループ 研究副主幹

3. (独) 日本原子力研究開発機構 地層処分研究開発部門 東濃地科学研究工 ニット 結晶質岩地質環境研究グループ

4. (独) 日本原子力研究開発機構 地層処分研究開発部門 東濃地科学研究工 ニット 結晶質岩工学技術開発グループサブグループリーダー

5. 大成基礎設計 (株) 国際事業部

[ 著者連絡先 ] FAX: 01632-5-2344 E-mail: sanada.hiroyuki@jaea.go.jp

キーワード : 光ファイバー, FBG，変位計，長期挙動，地層処分，幌延深 地層研究計画
道の周辺岩盤の長期的な挙動を知ることが求められている。しか しながら, 一般に岩盤中に設けられた構造物は, 建設時の安定性 評価に主眼が置かれており構造物の完成後の挙動についてはほと んどデータが取られていないのが現状である ${ }^{1,2)}$ 。また, 坑道周 辺岩盤中に生じる掘削影響領域が時間とともに拡大寸る可能性が あると考えられる ${ }^{3)}$ 。この領域は, 地下水や物質の主要な移行 経路になりうる可能性があることから, その地質環境特性の変化 を知ることは処分事業において重要な課題として位置付けられて いる。

一般に, 岩盤中に設けられた空洞には, 応力集中による損傷や 空洞周辺岩盤のクリープにより, 内空変位の増大や地中変位の変 動が生じる。これらの変位が許容值を越えると, 覆工の剥落や落 盤が生じ，空洞は所期の性能を発揮できなくなる可能性がある。 そのため, 上に記したような構造物の力学的な安定性の検討や監 視のために, 変位計などの計測器が地中に埋設され構造物内部の 


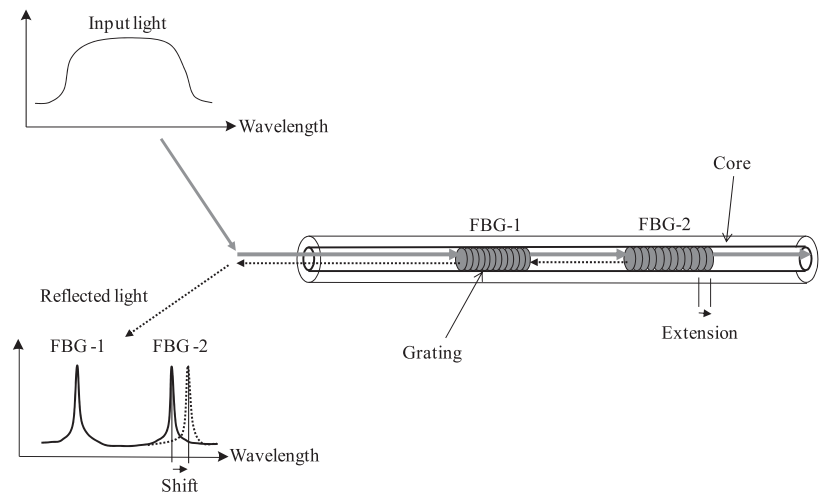

Fig.1 The measurement principle of the Fiber Bragg Grating for deformation monitoring.

変位が計測されることが多いが，その手段として，光ファイバー を利用した計測器の開発が近年進められている ${ }^{4-8)}$ 。

光ファイバーの地盤工学分野への適用という観点からは, トン ネルの変状 9-12) ・ 斜面の動態監視 13-15) ・ 送電鉄塔の沈下計測 16) - 間隙水圧測定 ${ }^{17)}$ ・ 温度計測 18,19$)$ - 流量観測 ${ }^{20)}$ ・地盤中の物質 の移行モニタリング ${ }^{21)}$ ・応力測定 ${ }^{22)}$ など各方面で積極的に実施 されている。その内, 変位計測については, レーザー光を利用し て非接触で計測するタイプ 23) などの例もあるが，測定対象に直 接設置して使用されることが多い。これまでのところトンネルや 斜面の表面を計測するタイプが主流で, 地中変位計への応用はそ れほど多くない。通常, トンネルや斜面の岩盤内部の変位は, 電 気式の多段式の変位計が使用されるが，ケーブルの絶縁不良など により長期の計測には向いていない。

光ファイバーケーブルは, 電気ケーブルと比較し, 長期的な耐 久性に優れる。これは, 光ファイバーは信号伝送媒体として石英 ガラスを用いているのに対し, 電気ケーブルは金属線を用いてい るからである。また, 光信号であっても減衰を示すが, 電気ケー ブルと比べると長距離伝送が可能である。そして，ケーブル断面 が遥かに小さいため, 小口径のボーリングで多段での計測が可能 になる。使用するボーリング孔が小さいとボーリング孔周辺に生 じる岩盤の乱れは小さくなる点でも利点が大きいと考えられる。 さらに, 光ファイバーは電気を使用しないため, メタンガスのよ うな可燃性ガスが存在する環境下でも計測することが可能となる。 また, 光ファイバーケーブルは, 主に通信などのインフラストラ クチャーにおいて利用されていることからわかるように, 大量の データを高速で長距離送信することができる。そのため, その機 能を用いることにより小径のケーブルで遠隔測定が可能であり, 電力の供給が難しい場合や計測器に苛酷な測定環境である場合に 測定対象近傍に測定機器やデータ取得用のコンピュータを配置す ることなく, 計測位置から離れた箇所から通信機器を介さずに直 接計測することが可能となる。したがって, 電気式の計測器と比 心簡潔で場所を取らない計測システムを構築することができる。

上記の背景から，筆者らは長期耐久性を有し，多段かつ高い精 度での計測を可能にするために, 光ファイバーを利用した多段式 の岩盤内変位計のプロトタイプシステムの検討と開発を行った。 光ファイバーケーブルは, 石英ガラスで構成されており, 後方散 乱光や反射光を利用することで, 微小な変位は計測可能なものの 大きな変位を計測するためには, 構造を工夫する必要があり, 筆 者らはこの問題の解決に重点を置いた。そして開発した変位計を 用いて実地盤における検証試験を行い原位置への適用性や作業性 の確認を行った。本論文では，上記の内容について論述する。

\section{2. 光ファイバーセンサーの選定と測定原理}

本章では，今回使用する光ファイバーセンサーの選定と測定原 理について述べる。現在地盤・岩盤工学において実用化されてい る光ファイバーセンサーは, FBG (Fiber Bragg Grating), B-OTDR (Brillouin Optical Time Domain Reflectometer), R-OTDR (RamanOptical Time Domain Reflectometer), OTDR (Optical Time Domain Reflectometer), OSMOS (Optical Strand Monitoring System), SOFO (Surveillance d'Ouvrages par Fibres Optiques), Fabry-Perot がある。 B-OTDR, R-OTDR および OTDR の各方式は連続測定が可能であ るが, 変位測定の実用精度が岩盤中の変位を高精度で計測するに は若干低いと考えられている。また, OSMOS, SOFO, Fabry-Perot の各方式は, 1 本の光ファイバーケーブルで 1 点 (あるいは 1 区 間 ) の計測をする方式であり, 多連装での計測を行うには複数の ケーブルを用意する必要があり, 多段での計測を行う場合にはや や不利と考えられている。一方, FBG は, FBG 単体をひずみゲ 一ジの代用として使用した場合, 分解能がおおよそ $1 \mu$ である。 そして，1本のケーブルで多点での計測が可能であり, 連続モニ タリングも行える。上記の理由から, 本研究では地中変位計に利 用する光ファイバーとして FBG を採用寸ることにした。

FBG は, 光ファイバーのコア部分に屈折率を変化させた周期 的回折格子であるブラッグ回折格子を形成したもので, 特定の波 長の光のみを反射する。Fig. 1 に FBG の構造を模擬したものを 示す。ファイバーコア内に広帯域光を入射すると, FBG の周期 で決定される特定の波長 $\lambda$ の光のみが反射し, 他の波長の光は 透過する。

ブラッグ波長近傍の波長 $\lambda_{\mathrm{B}}$, コアの屈折率 $n_{0}$, グレーティング の間隔 $d$ の関係は, 式 (1) で表わすことができる

$\lambda_{\mathrm{B}}=2 n_{0} d$

FBG の軸方向にひずみ $\varepsilon$ が作用すると, グレーティング間隔 と屈折率が変化し, 式 (2) に示すように $\Delta \lambda_{\mathrm{B}}$ だけ波長が変化する。

$\Delta \lambda_{\mathrm{B}}=\lambda_{\mathrm{B}}\left(1-\rho_{\mathrm{c}}\right) \varepsilon$

ここで， $\rho_{\mathrm{c}}$ はひずみによる屈折率変化を与える係数である。

式 (2) によって, FBG にひずみ変化が生じた場合, ブラッグ波 長のシフト変化を測定することでひずみが得られることが分か る。FBG に温度変化 $\Delta T$ が作用した場合でも, 屈折率およびグレ 一ティング間隔が変化するため, 式 (3) のようにブラッグ波長が 変化する ${ }^{24)}$ 。

$$
\Delta \lambda_{\mathrm{B}}=\lambda_{\mathrm{B}}(\xi+\alpha) \Delta T
$$

ここで, $\xi$ は屈折率の温度変化率， $\alpha$ はグレーティング間隔の 温度変化率である。

上記の原理から FBG を利用し, 反射波の波長を計測すること でFBG に作用した変位や温度を計測することが可能となること がわかる。そして, FBGの特徵としてグレーティングを通過し た透過光は, グレーティング間隔に対応した部分の波長 (ブラッ グ波長 ) は久損するが，その他の波長はそのまま透過する。その ため, グレーティング間隔の異なる FBG を連結し, 透過光を利 用して計測することで 1 本のケーブルで多段での計測を行うこと ができる。この特性を利用し, 波長の異なる FBG を順次連結す ることで, 1 本の光ファイバーケーブルで $5 \sim 20$ 程度のデータ を測定することができる。 


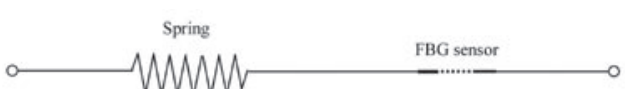

Fig.2 The structure to attenuate the large displacement
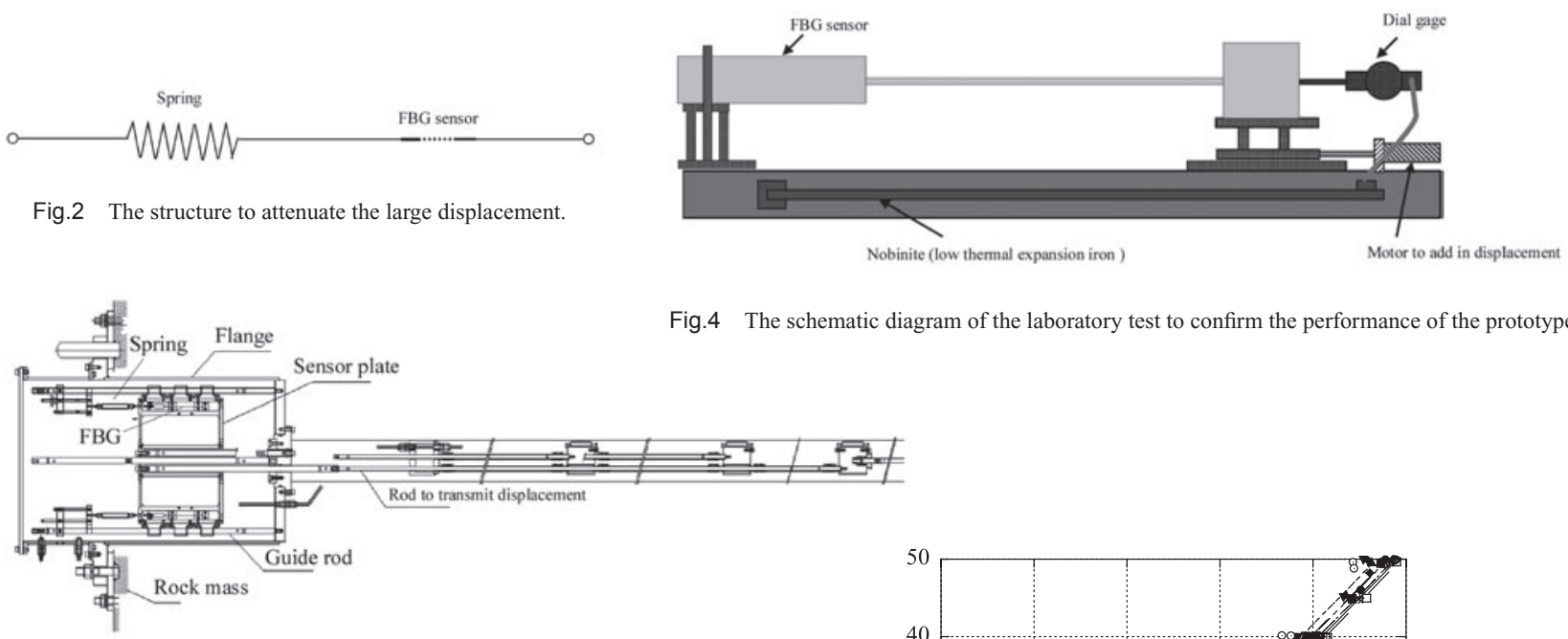

Fig.3 The structure of Sensor A.

\section{3. 開発した変位計の構造と室内検定試験}

本章では, 開発した変位計の仕様・構造と変位計の校正係数の 算出や性能を確認するために室内での検定試験の詳細について述 べる。岩盤中に設けられた空洞周囲岩盤の変位は, 一般に自由面 近傍で大きく, 深部に進むにつれて小さい。そのため, 構造物周 囲に生じる大きな変位と小さな変位をカバーすることができる ように 3 種類の測定範囲 $(50 \mathrm{~mm}, 7 \mathrm{~mm}, 1 \mathrm{~mm})$ を持つ測定器を開 発することにした (以下に記す大変形用センサーは測定範囲 50 $\mathrm{mm}$ (Sensor A), 微小変形用センサーは測定範囲 $7 \mathrm{~mm}$ (Sensor B) と $1 \mathrm{~mm}$ (Sensor C) を示す)。本研究では $13 \mathrm{~m}$ 程度の領域を精度 よく計測することを念頭に置き開発を行った。そして，使用する ボーリング孔はボーリング周囲に生じる掘削影響を最小化するた めに一般的なコアボーリングの最小径である直径 $66 \mathrm{~mm}$ とした。 Sensor A と Sensor B の測定精度については, FBG 方式の一般的 精度である $0.5 \%$ をとし, Sensor C については, $1 / 100 \mathrm{~mm}$ 末満の 精度検証が技術的にかなり困難であるため $1 / 100 \mathrm{~mm}$ の区間変位 とした。なお，使用する光ファイバーケーブルは通信用の標準で あり，長距離データ伝送が可能なシングルモード石英ファイバー ケーブルを使用した。以下に大変形用センサー (Sensor A) と微小 変形用センサー (Sensor B, C) の構造と室内検定試駼結果について 記す。

\section{$3 \cdot 1$ 大変形用センサー $($ Sensor A)}

本章では, 大変形用センサーの構造と室内検定試験について 述べる。FBG 加工した光ファイバーケーブルの破断ひずみは $1 \%$ $(10000 \mu)$ であり, 許容されるひずみは安全率を考慮してセンサ 一としての使用範囲を $3000 \mu$ とした。これを計測区間 $1 \mathrm{~m}$ あた りに換算すると $3 \mathrm{~mm}$ となる。したがって, FBG 加工した光ファ イバーケーブルを $1 \mathrm{~m}$ あたり $3 \mathrm{~mm}$ 以上の測定範囲を持つセンサ 一として使用する場合には，変位を減衰する機構が必要である。 本研究においては, 変位減哀装置として Fig. 2 亿示寸ようにバネ を組み込む方式とした。なお，浅部は変位量が大きいため，測定 区間から坑口までロッド変位を伝達して孔口付近で測定する形式 をとることが可能である。Fig. 3 亿大変形用センサーの構成を示 す。各測定深度には, ステンレス製の変位伝達ロッドが連結され た金属式のアンカーが設けられており，孔口部分にはバネが組み 込まれ変位隇衰装置が設置される。アンカーは孔口部分に設置さ れた変位減衰装置にロッドを介して連結されているため, アンカ

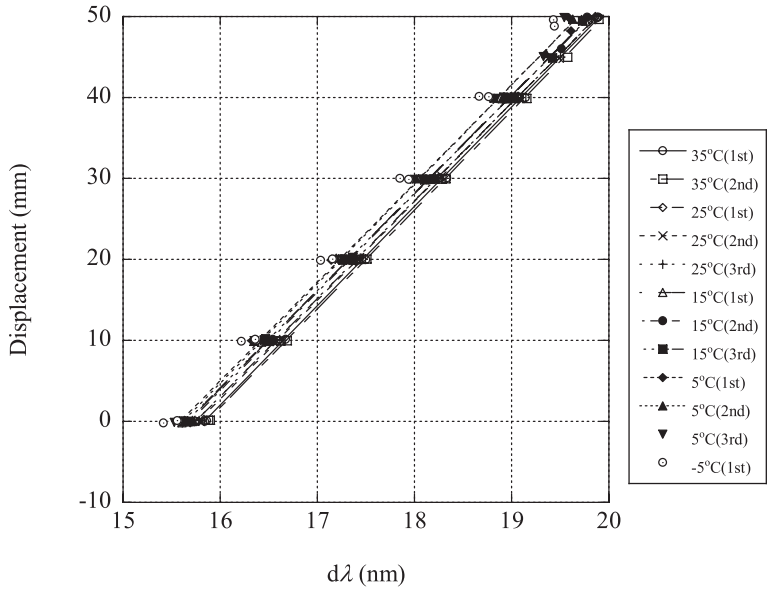

Fig.5 Relationship between the variation of wavelength and displacement for Sensor A.

一と孔口間の移動量を計測する機構となっている。また，変位減 衰機構内にあるロッドは FBG を収納するためのプレートに固定 されている。変位を減衰するためにフランジ内にバネが FBG と 直列で配置されており FBG の変位を抑制することが可能となっ ている。アンカーについては, ゴム式の膨張式アンカーや機械式 アンカーや金属膨張式アンカーが存在するが，恒久的に保持する ために銅による金属膨張式アンカーを採用することにした。これ は, アンカーラインから注水された水によりアンカーを塑性変形 させ岩盤に固定させる。なお, 光ファイバー収納スペースをセン サー本体内部に確保し, 光ファイバーケーブルの余長部分も収納 できる構造とした。そして, ロッドの支持部は摩擦を低減するた めテフロン製とした。変位伝達ロッドのたわみ防止のため, ステ ンレス製ガイドロッドとテフロン製ガイドを設けている。なお， この構造では, 光ファイバーを金属プレートに接着寸る必要があ るが，十分な接着面積を確保するために，金属プレートに半円型 の溝を加工し，センサーにヒステリシスが生じないように改良し た。具体的には, 被覆を剥いた光ファイバーの外径が $0.125 \mathrm{~mm}$ であることから, 溝の直径は最細部で $0.15 \mathrm{~mm}$ とした。

室内検定試験の状沉を Fig. 4 亿示寸。室内検定試験は, 恒温 槽を利用して変位制御モーターにて人為的に変位を与え変位 - 波 長 - 温度変化との対応関係を調べた。なお，変位の検出基点とし ては線膨張係数が鋼材より 1 桁小さいインバー製の棒を用いた。 Fig. 5 亿波長変化量と人為的に与えた変位との関係を示寸。変位 は, $-5^{\circ} \mathrm{C} \sim 35^{\circ} \mathrm{C}$ 範囲内で $0 \sim 50 \mathrm{~mm}$ まで $10 \mathrm{~mm}$ ピッチで複数

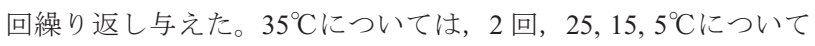
は 3 回, $-5^{\circ} \mathrm{C}$ にいては 1 回繰り返し変位を与えた ( 凡例に示寸 


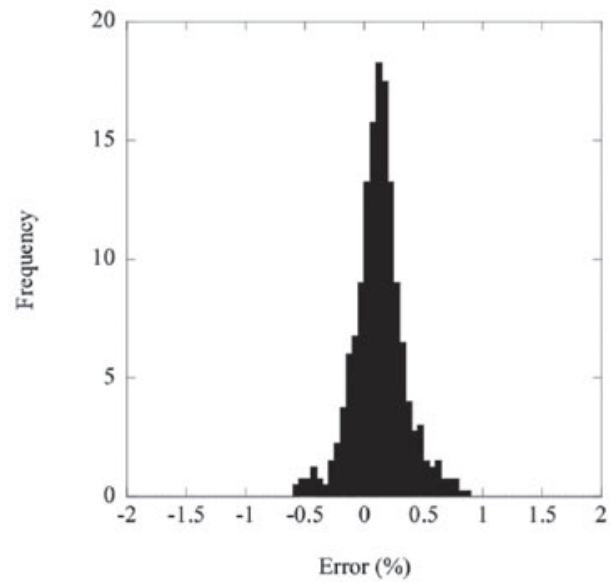

Fig.6 Sensor A -error histogram.

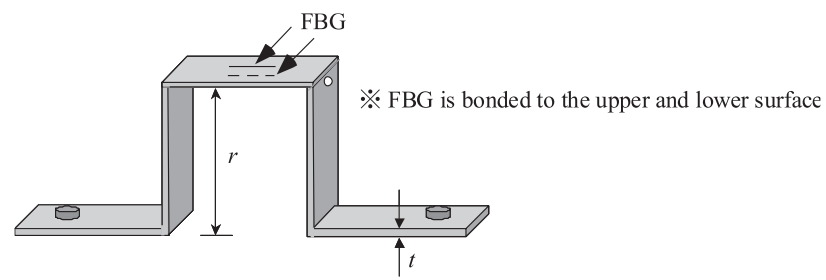

Fig.7 Design for temperature compensation in Sensor B and C.

1st とは 1 回目, 2nd とは 2 回目, 3rd とは 3 回目を示す)。なお, $\mathrm{x}$ 軸は測定された波長から $1541 \mathrm{~nm}$ を引いた值を示している。図 には, $35^{\circ} \mathrm{C}$ から $-5^{\circ} \mathrm{C}$ までの範囲で合計 12 個の室内検定試験の結 果を示しているが，いずれも与変位量と波長変化量との対応は良 好であり, ほぼ線形的に増大している。図に示寸線分は, 室内検 定試験で得られたプロットを線形近似したものを示しているが, 相関係数は全ての線分においてほぼ 1 である。Fig. 6 に上記のセ ンサーの誤差分布をヒストグラム化した図を示す。ここでの誤差 とは，与変位量に対する与変位量と波長変化量から算出した変位 量との差を除し百分率で表したものを示す。この結果によると誤 差は，概ね $1 \%$ の範囲内に分布しその多くは土 $0.5 \%$ の範囲に高 いピークを持つ。形状としては, 誤差 $0 \%$ を中心とした正規分布 に近い形を示している。大変形用センサーについては, 測定範囲 を $1 \mathrm{~m}$ と仮定すると誤差が概社 $1 \%$ の範囲内に分布していること から $0.5 \mathrm{~mm}$ 程度の分解能を有寸ると考えられる。

\section{$3 \cdot 2$ 微小変形用センサー (Sensor B, C)}

微小変形用センサーについては, 本研究の初期においてアンカ 一の間をテンドン (張力をかけた線) で連結しテンドンに取り付 けた FBG で変位を検出するプロトタイプの作成を試みた ${ }^{25)}$ 。し かし, このタイプの場合構造的に弱くボーリング孔の状態が悪い 場合には挿入が困難であることや張力を調整するためのモーター の防水が困難であるという課題があった。そこで, 構造の強化と 防水機能を持たせるため, 自己温度補償素子型の変位計を製作す ることにした。Fig. 7 に自己温度補償素子型の変位計を示す。こ の素子は, 変位を薄板の曲げに変換して計測するものであり, 曲 げ部材の上下両面に FBG を取付けて計測することによって温度 補償できる形式となっている。部材に加わる変位と部材の高さと 厚みとの関係は以下の式で表現できる。

$$
\varepsilon=\frac{\sigma}{E}=\frac{3 \Delta l t}{4 r^{2}}
$$

ここで, 部材の高さは $r$, 部材の厚さは $t$, FBG のひずみは $\varepsilon$, 部材に加わる変位は $\Delta l$, 薄板の応力は $\sigma$, 薄板の弾性係数は $E$ である。Sensor B と C の違いは, 測定レンジに関連するパラメ ータである $r$ と $t$ が異なることである。

センサーの可動域は構造的に制限されているため, 挿入時もし くは引抜時に素子に過負荷が作用しない構造にしている。室内検 定試験については，大変形用センサーと同様に恒温槽内部で人 為的に温度と変位を与え, それと波長変化との関係を検討した。 なお, Sensor Bについては, 通常 $-2 \mathrm{~mm} \sim 5 \mathrm{~mm}$ までの測定範 囲を有するが, 今回は $-5 \mathrm{~mm} \sim 5 \mathrm{~mm}$ までの $10 \mathrm{~mm}$ の変位を作 用させた。Fig. 8 に, Sensor B と C の波長変化と与変位量との関 係を示す。なお, Sensor B については表面波長 $\lambda_{\text {upper }}$ と裏面波長 $\lambda_{\text {lower }}$ の差に $15 \mathrm{~nm}$ 加えたものを, Sensor C については表面波長 と裏面波長の差に $12 \mathrm{~nm}$ 加えた形で整理した。いずれのデータも 大変形用センサーと同様に波長変化と与変位量との相関が良く, 概初線形近似できる。そして, 相関係数はほぼ 1 を示した。誤 差分布を示すヒストグラムは, Sensor B でほぼ $0.5 \%$ 以内を示し, Sensor C においても概ね $0.01 \mathrm{~mm}$ の範囲内に分布している。いず れも誤差 $0 \%$ を基準として正規分布に近い形状を示しており, 本 研究で目標としている分解能を概ね満たすものと考えられる。

次に, 微小変形用センサーの自己温度補償機能を確認するため にセンサーを恒温槽に入れ, 恒温槽内部の温度を $30^{\circ} \mathrm{C}$ から $0^{\circ} \mathrm{C}$ ま で変化させ, センサーの算出変位の挙動を調べた。Fig. 9 にセン サー付近の温度とセンサーの相対波長変動量の経時変化を示す。 なお, 温度は白金温度計で計測した。Sensor Bについては, 試験 開始後, 約 1 時間経過した時点で $30{ }^{\circ} \mathrm{C}$ 与えたときに波長が 15 $\mathrm{pm}$ ほど変動した。この $15 \mathrm{pm}$ という変動幅は FBG 接着部に残 っていた残留ひずみであり, 温度変動を与えることで消失したと 考えられる。温度変化時の波長挙動は温度安定時の波長挙動と比 較すると若干大きな動きを示しているが，これは表面と裏面の温 度反応差から生じるものである。これは急激な温度変動が生じた ときに現れる現象であり, センサー性能には影響しないと考えら れる。その後の波長変動幅は $6 \mathrm{pm}$ 程度であった。これは, セン サーが仕様測定範囲で使用寸る波長幅である $3200 \mathrm{pm}$ に対して $0.2 \%$ となり, 誤差の範囲であるといえる。一方, Sensor C につ いては, 波長変動幅は約 $3 \mathrm{pm}$ であった。この結果はセンサーが 仕様測定範囲で使用する波長幅である $1000 \mathrm{pm}$ に対して $0.3 \%$ と なり, 波長変動幅としては非常に小さく, 十分な自己温度補償を 有していると考えられる。

\section{4. 実地盤における検証試験}

前章までで, 変位計を開発するに至った経緯, 仕様検討, 室内 における性能確認試験について述べた。上記の検討結果に基づき, 本章では光ファイバーを利用した多段式変位計のプロトタイプを 作成し, 原位置での作業性や適用性を確認するために実地盤にお ける検証試験を行った。以下にその内容について述べる。

\section{$4 \cdot 1$ プロトタイプの製作と設置}

今回の実地盤における検証試験で作成した変位計は, 孔口から 順番に $1 \mathrm{~m}$ 間隔で Sensor A が 4 台, Sensor B が 1 台, Sensor C が 1 台連結されたものを製作した。Sensor B, Cには, 2 本の光ファ イバーが接続されており，1 本は計測用ライン，1 本は計測ライ ンが断線した場合のための計測用予備ラインである。

ボーリングは, 実験室の敷地内の地盤で実施した。計測システ ムとボーリング設置図ならびに計測器の全体図を Fig. 10 に示す。 ボーリングは, 直径 $66 \mathrm{~mm}$ で深度約 $6 \mathrm{~m}$ であり, 水平面から鉛 直下向きに 10 度傾斜させた方向に掘削した。周辺の地質は, 中 


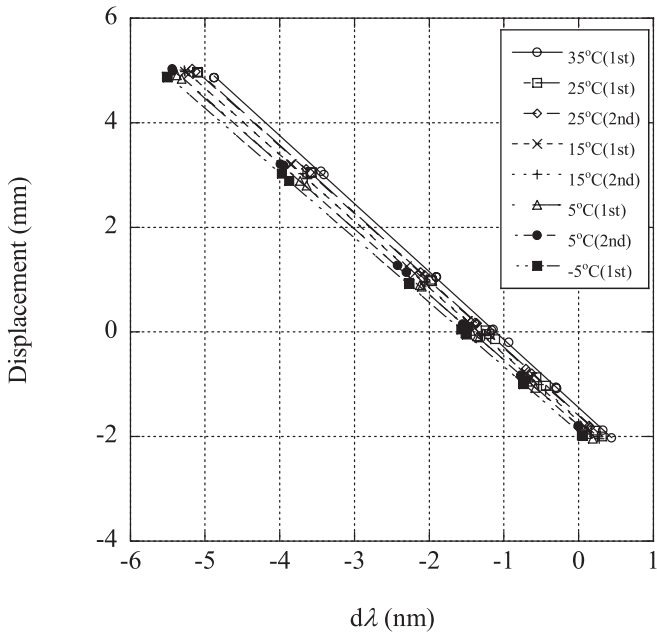

(a) Relationship between the variation of wavelength and displacement for Sensor B

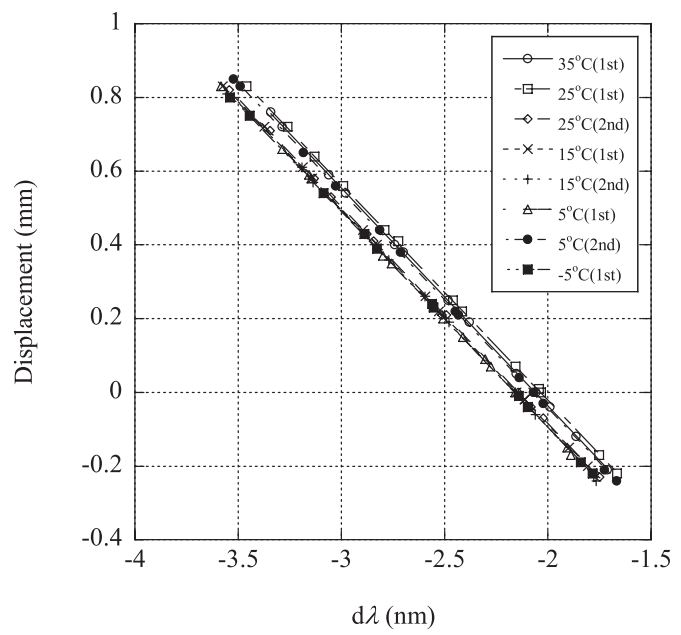

(b) Relationship between the variation of wavelength and displacement for Sensor C

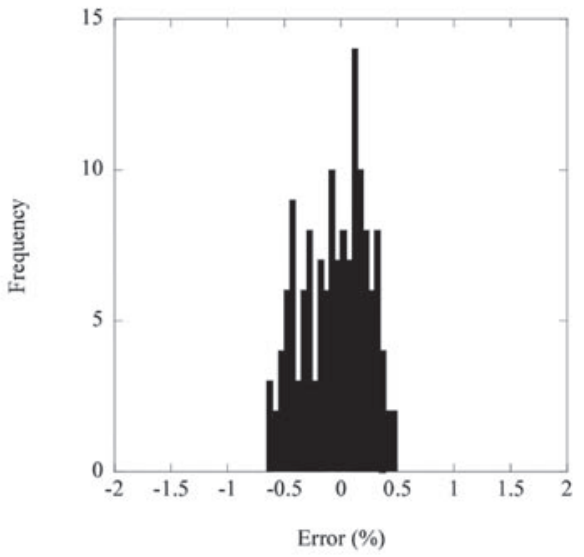

(c) Sensor B -error histogram

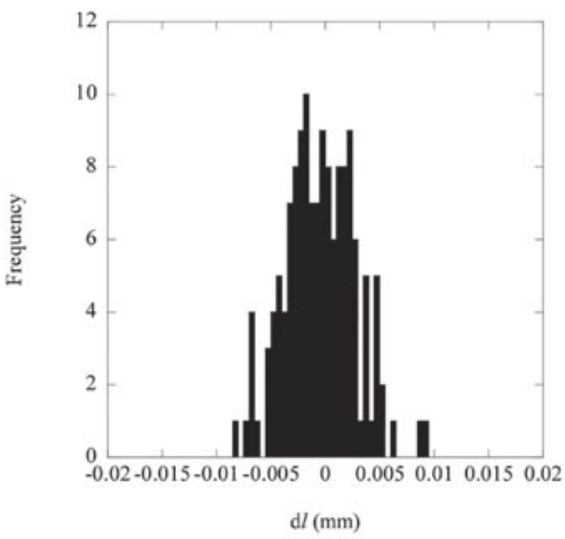

(d) Sensor C -error histogram

Fig.8 The results of the laboratory test.

古生層が破砕され一部粘土化した粘板岩を主体としており所々に 砂岩を挟んだ地質構成であった。現地は, 平地で岩盤が GL-1.4 $\mathrm{m}$ から分布する条件であったため, 地表面から岩盤までを掘削し た後に中間部をコンクリートで置換した。なお, 孔口は深度 $1 \mathrm{~m}$ ほどのピットを掘削している。

変位計の設置は以下の要領で実施した。

(1) ボーリング孔への挿入

(2) アンカーの拡張

(3) グラウト注入

(4) 孔口装置の設置

(5) 浅部測定装置の設置

(6) 光ファイバーケーブルの接続

(7) 測定機器の設置

ボーリング孔への挿入には, 変位計の上部 $3 \mathrm{~m}$ と下部 $3 \mathrm{~m}$ をそ れぞれに分割し挿入した。変位計の挿入後, グラウト充填を行う 必要があるが, その際変位伝達ロッドをグラウト材から保護する ためにロッドと変位計の接続部分を熱収縮チューブで覆った。な お, 現地一の搬入の際にロッドの稼働を制限するためにロッドロ ックを設けている。変位計の挿入には, まず設置前にグラウト注 入パイプを孔内に挿入し，このパイプをセンサー挿入ガイドとし て変位計を挿入した。設置完了後は, センサーの健全性を確認す
るために, 可視光線を入光させセンサーの断線などがないことを 確認した。そして, 設置後に水圧ポンプにてアンカーを拡張させ 固定した。通常の電気式変位計の場合も同様であるが, 変位計設 置後にグラウト充填されるケースが多い。これは, 新たな水みち の形成を防ぐことがあることに加え, 長期間での計測を考えた場 合, 孔壁の崩壊によってメカニカルアンカーが効かなくなるリス クを考慮に入れて行うものである。グラウト材はセメントーベン トナイトの混合材である TM セッター (立花マテリアル社製) を 使用した。これは, 硬化後の体積収縮が少ない。

孔口装置は, 開発した変位計の性能確認を行うために孔口のコ ンクリートに固定せずに, フランジにネジを切りボルトの回転に より $50 \mathrm{~mm}$ までの動きが可能な構造とした。光ファイバーケー ブルの孔口部での接続は, 融着接続機で行った。光ファイバーケ ーブルの接続は, 光コネクタでも可能であるが, 融着接続の方が 伝送損失が少なく, 長期的に安定な接続が期待できる。孔口部か ら測定機器のある室内までの $50 \mathrm{~m}$ は, 4 心テープ心線と呼ばれ る 4 本の光ファイバーを平たく並ベた形の光ファイバーケーブル を内蔵した屋外配線用ドロップケーブルを敷設した。計測システ ムについては, Fig. 10 に示されている。孔口から引き込まれた 光ファイバーケーブルは, 4 チャンネルの光スイッチを経由して, FBG 波長測定器に接続される。光スイッチと FBG 波長測定器は 


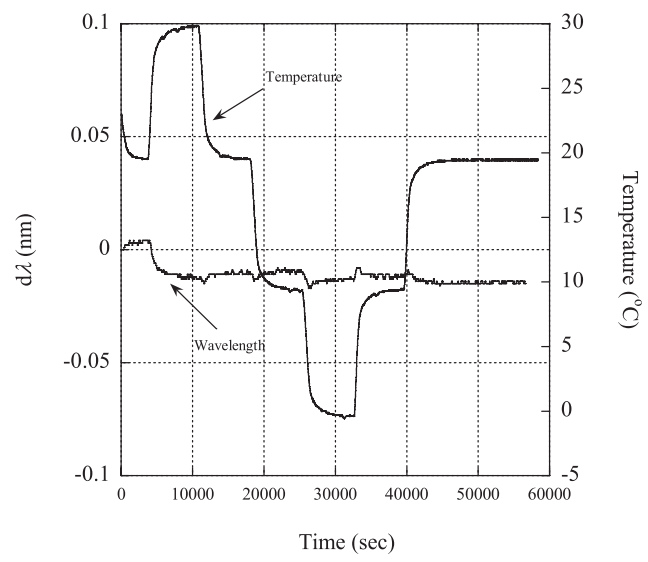

(a) Sensor B

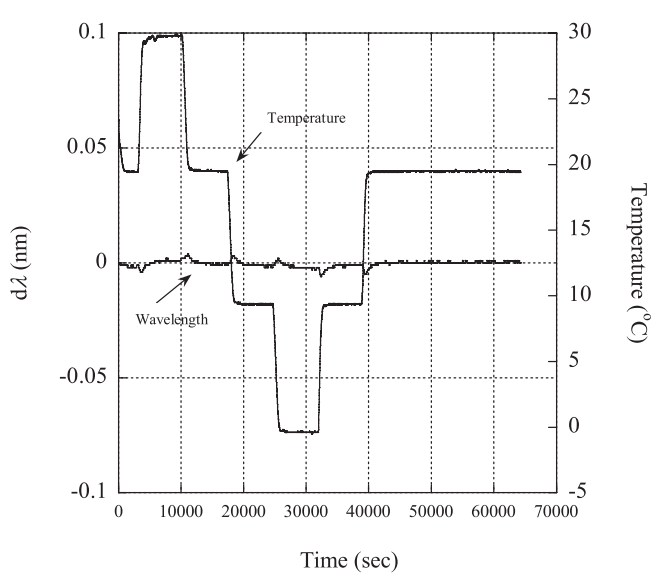

(b) Sensor C

Fig.9 Result of the verification test about the temperature compensation.

PCによって制御され，データは常時監視できる。また，測定デ ータはPC に保存されるシステムとなっている。

\section{$4 \cdot 2$ 原位置での作業性と適用性についての検討}

本章では, 設置状況と原位置計測結果から今回開発した変位計 の原位置での作業性・適用性について検討する。光ファイバーを 計測器として使用することの主なメリットは, 長期的な耐久性を 有すること・小口径であること・大量のデータを長距離伝送でき ることなどが挙げられる。ただし, ケーブルが石英ガラスで構成 されていることから, 電気式のケーブルと比べると設置時の取り 扱いに注意が必要である。また, ケーブルに曲げが発生すると伝 送光の減衰が増加しケーブルの引張強度が低下寸ることが知られ ている。先に記したが, 本研究の初期で開発した変位計は ${ }^{25)}$, 光ファイバーに直接張力をかけた線に接着されており, 構造的な 強度は脆弱であった。そのため, 過去に本論文で示した実地盤に おける検証試験箇所と同一のサイトに掘削したボーリング孔を用 いて計測を試みた ${ }^{25)}$ が，構造的な強度不足の問題で装置の損傷 が幾分か生じ, 装置の設置が困難であった。特に光ファイバーを 用いた計測器の場合, 無理な挿入を行うとファイバー自身に重大 な損傷を生じる恐れがあり，致命的な問題になる可能性がある ( 軽微な損傷であっても, ガラス内部に微細なクラックが生じる と過大な応力集中が生じる)。その点, 今回開発した変位計を用 いた実地盤における検証試験では, 過去のタイプの変位計と比べ ると ${ }^{25)}$ ，スムーズに挿入することができ，構造的な強度不足は 改善されたと考えられる。固定時に使用する銅アンカーや設置後 に充填するグラウト材の注入は, 通常使用される電気式の変位計

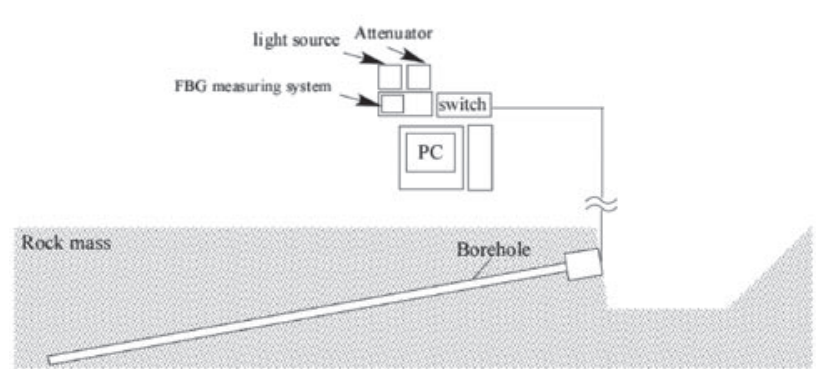

(a) System and layout

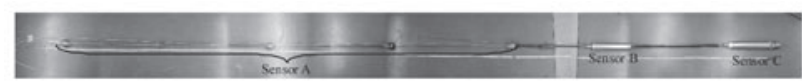

(b) Photo of displacement sensor

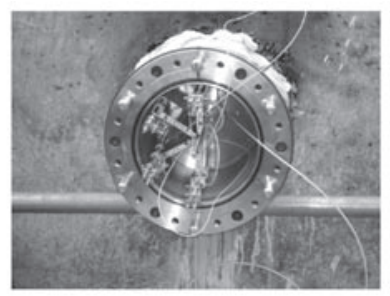

(c) Surface of unflanged displacement sensor

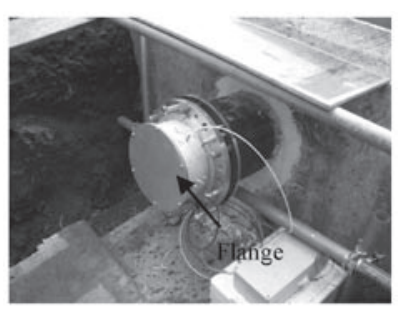

(d) Surface of flanged displacement sensor

Fig.10 The layout of in situ test and displacement sensor.

においても普通に実施されているものであり, 本研究で開発した 変位計の実地盤における検証試験においても, 作業性という観点 において, 大きな問題はなかった。測定システムも計測装置を計 測箇所付近に置く必要がなく, システム整備という意味でも簡易 と考えられる。

経過時間と変位およびセンサーで測定された温度を Fig. 11 に 示す。浅部のセンサーは, 所定の時間 (数日) 経過後人為的に 5 回変位を与え, その值はそれぞれ $12.27 \mathrm{~mm}, 8.18 \mathrm{~mm}, 9.93 \mathrm{~mm}$, $9.95 \mathrm{~mm}, 10.40 \mathrm{~mm}$ をボルトの回転により順に与えた。なお, 計 測は 1 カ月程度行った。図に示寸 (a) は与えた変位と時間との関 係，(b)，(c) はそれぞれ Sensor A の内アンカーがボーリング孔内 の $1 \mathrm{~m}$ に設置してあるセンサーの温度と変位, (d) は Sensor B と C の変位を示す。Sensor A の結果については深度で大きな差異が 見られなかったので上述したように $1 \mathrm{~m}$ 箇所の結果のみを載せ た。Sensor B と Sensor C は全データにおいて特に異常 ( 欠損) を 示す結果は見受けられず, 安定した測定結果となった。Sensor A については, 人為的に与えた変位と光ファイバーの測定波長から 求めた変位との対応は良く, 原位置の岩盤変位に追従しており良 好に機能していると考えられる。Sensor B, C は与えた変位と対 応しない。これは構造上の違いによる。Sensor A の構造は, ロッ ドが FBG，バネに直列に接続されており，ボーリング孔口のフ 


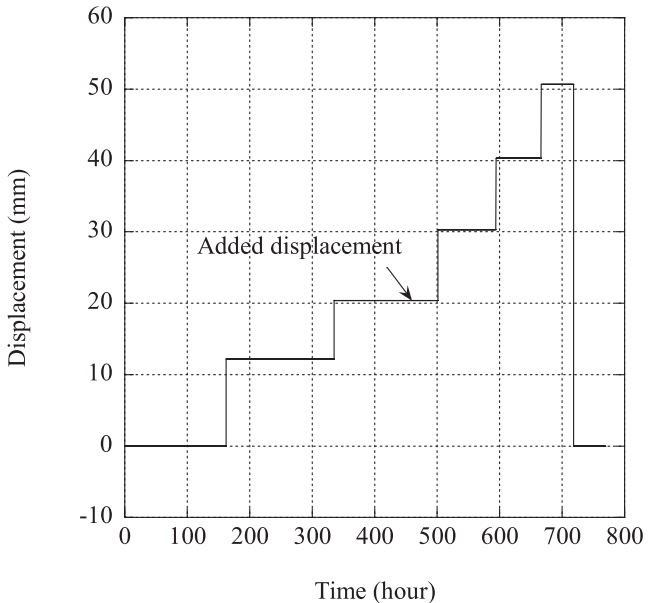

(a) Added displacement

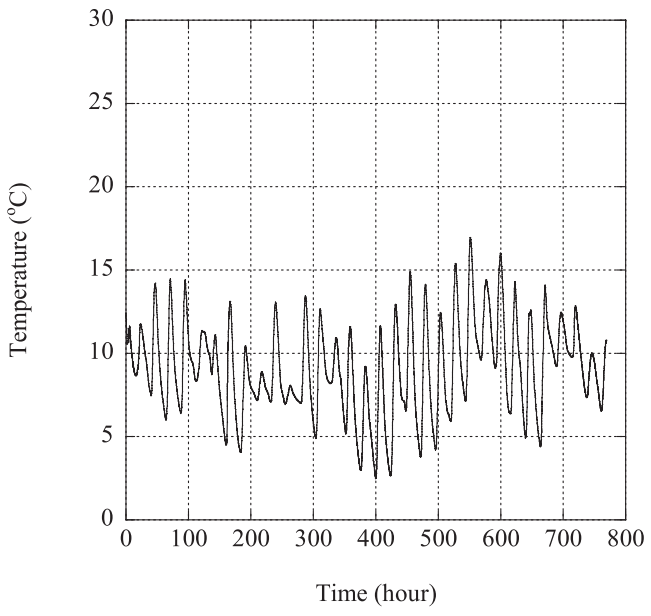

(b) Temperature around the surface of the borehole

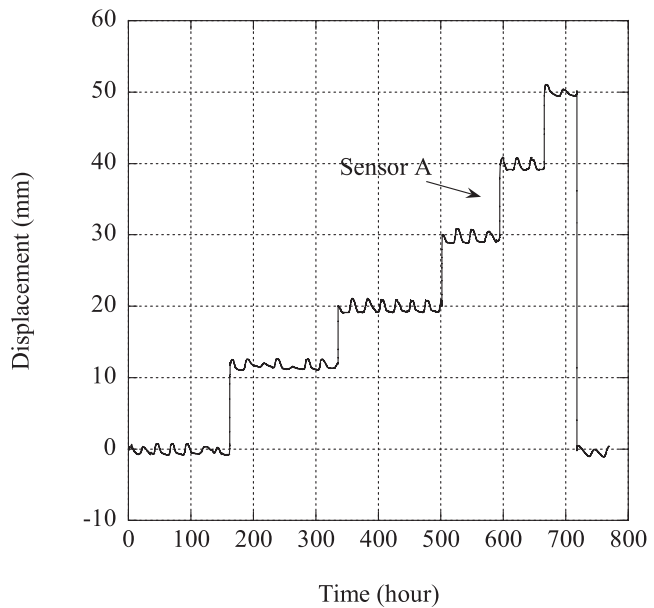

(c) An example of monitoring by sensor A

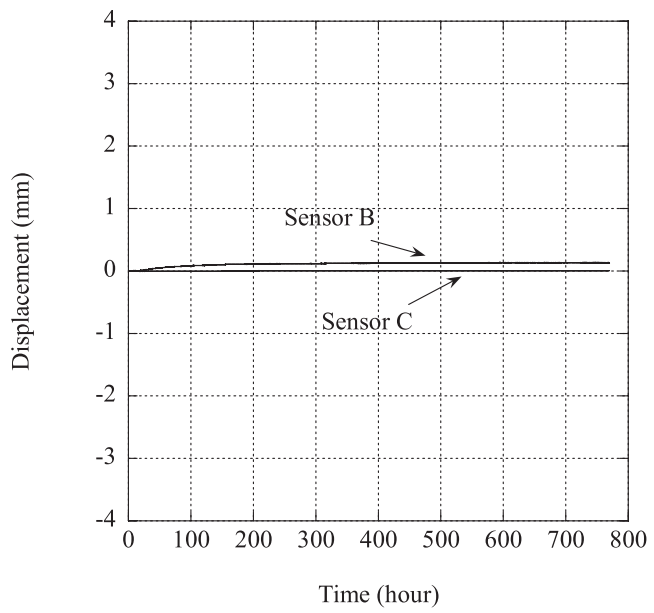

(d) Monitoring by sensor B and C

Fig.11 The results of in situ test.

ランジに固定されている。そのため，アンカーとフランジの間の 変位が計測される構造となっている。一方, Sensor B, C は, ア ンカーとアンカーの間に FBG が接着されているため, 岩盤中に 設置されたアンカー間の距離を計測する機構となっている。その ため, 与えた変位とは対応しない。また, その他の特徴的な挙動 としては外部の温度や気圧などの外的環境に対応すると考えら れる微小な変動が見られる。これは, Sensor A では見られるが, Sensor B, C では見られない。なお, 今回設置した変位計は, 孔 口箇所はコンクリート置換されている。理科年表によるとコンク リートの線膨張係数は, $1.4 \times 10^{-5}$ であり理論上は外気温の変化 に上記の線膨張率と物質の長さ分を乗じた量だけ変位が生じる。 また, 外気圧の変動も, 計測変位に影響を与えるものと考えられ る。今回の Sensor A は, 外気圧や温度変化などの周期的な日変 動を計測しているようにも見受けられ，センサー周囲の微小な環 境の変化をモニタリングしているものと思われる。センサー周囲 の測定環境の変動には温度の変化に加え, 気圧・湿度など複数の 外的要因が加わっているものと想定され, 計測環境の変動は極力 小さいことが望ましいと考えられる。しかし，プロトタイプの開 発という点では, 作業性については光ファイバー自身が有する構 造的な強度不足を克服し, 室内検定試験から本研究で設定した測 定精度は概小満たしていたことから，原位置での適用可能性に関
する見通しを得たと考えられる。

\section{5. 結言}

本研究では, 長期耐久性を有し, 多段かつ高い精度での計測を 可能にするために, 光ファイバーを利用した多段式の岩盤内変位 計のプロトタイプシステムの検討と開発を行った。そしてプロト タイプシステムを用いた実地盤における検証試験から, 原位置へ の適用性や作業性の確認を行った。また, 変位計の性能を確認す るために, 恒温槽内にて変位・温度を変化させた室内検定試験を 行い, ブラッグ波長の変化量との対応関係を整理し, 校正式を求 めた。それを用い算出した変位と実際に与えた変位量との比較か ら, 今回開発した变位計は本研究で設定した測定精度 (測定範囲 の $0.5 \%$ または $1 / 100 \mathrm{~mm}$ ) を概社満足していた。さらに, 原位置 での作業性と変位計の性能の確認のために実地盤における検証試 験を実施した結果, ブラッグ波長の変化量から算出した変位は, 実際に与えた変位量と良く一致していたことに加え, 作業性や作 業時間についても通常用いられる電気式の地中変位計と同等程度 であり, 原位置計測の実現可能性についての見通しを得ることが できた。今後は, 開発した地中変位計を実際の地質環境に対し適 用し，その適用可能性を確認するとともにさらなる改良に努める 必要がある。 


\section{References}

1) JNC: JNC TN1400 99-020, (JNC, Tokai, 2000) .

2) T. Aoki, S. Nakama, T. Sato and S. Okubo: Journal of MMIJ, 121 (2005) , 489-497.

3) C. Tsang, F. Bernier and C. Davis: Int. J. Rock Mech. \& Min. Sci., 42 (2005) 109-125.

4) R. M. Measures: Composites Engineering, 3 (1993) , 715-750.

5) H. Li, D. Li and G. Song: Engineering Structures: 26 (2004) , 1647-1657.

6) M. Majumder, T. K. Gangopadhyay, A. K. Chakraborty, K. Dasgupta and D.K. Bhattacharya: Sensors and Actuators, 147 (2008) , 150-164.

7) P. Ferraro and G. D. Natale: Optics and Lasers in Engineering, 37 (2002), 115-130.

8) G. Brambilla, H.H. Kee, V. Pruneri and T.P. Newson: Optics and Lasers in Engineering, 37 (2002), 215-232.

9) W. Cheng and J. Ni: Tunnelling and Underground Space Technology, 24 (2009), 331-349.

10) C. Li, Y. Zhao, H. Liu , Z. Wan and C. Zhang and N. Rong: Automation in Construction, 17 (2008), 641-644

11) N. Metje, D. N. Chapman, C. Rogers, P. Henderson and M. Beth: Tunnelling and Underground Space Technology, 21 (2006), 417.

12) S. Bhalla, Y.W. Yang, J. Zhao and C.K. Soh: Tunnelling and Underground Space Technology, 20 (2005) , 487-500.

13) F. Cappa, Y. Guglielmi, S. Gaffet, H. Lancon and I. Lamarque: Int. J. of Rock Mech. \& Min. Sci., 43 (2006) , 647-654.
14) T. Guo, W.Yuan and L.Wu: Optics and Lasers in Engineering, 47 (2009) ,156-160.

15) Y. Yoshida, Y. Kashiwai, E. Murakami, S. Ishida and N. Hashiguchi: SPIE's 9th Annual International Symposium on Smart Structures and Materials, (2002), pp. 296-303

16) S. Irie, M. Yukizaki and R. Hirata: Tunnels and Underground, 7 (2009), 501-507.

17) S. Takeuchi, Y. Kashiwai, Y. Hirata, Y. Yoshida and M. Nishigaki: Workshop on Fibres and Optical Passive Components, (2005), pp. 393-398.

18) E. Hurtig, S. Groubwig, M. Jobmann, K. Kuhn and P. Marschall: Geothermics , 23 (1994), 355-364.

19) A. Lonnermark, P. O. Hedekvist and H. Ingason: Fire Safety Journal, 43 (2008) , 119-126.

20) C. G. Campbell, D. T. Laycak, W. Hoppes, N. T. Tran and F. G. Shi: Journal of Hydrology, 311 (2005), 244-253.

21) A.C.J. Treadaway, R.J. Lynch and M.D. Bolton: Engineering Geology, 53 (1998), 195-204.

22) K. A. Heasley, T. H. Dubaniewicz, M. D. DiMartino: Int. J. Rock Mech. \& Min. Sci., 34:3-4 (1997), paper No.066.

23) S.C. Blair, D. Sweider, S. Trettenero and C. Boro: Int. J. Rock Mech. \& Min. Sci. 34:3-4 (1997), Paper No.029.

24) R. Nakano, S. Miura, M. Imai, K. Nakamura, T. Saito, Y. Takahashi and H. Iida: Dynamics and Design Conference, 07-08 (2007), CDROM.

25) Y. Kashiwai, H. Sanada and H.Matsui: JAEA-Technology 2008-046 (JAEA, Tokai, 2009). 